SOUMHYA VENKATESAN

University of Manchester

\title{
The social life of a "free" gift
}

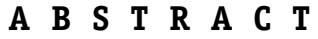

In this article, I continue the anthropological interest in gifting. I trace the story of a historical failed gift of a South Indian woven mat to Queen Elizabeth II, which, in later accounts was transformed into a successful gift. Identifying this mythical successful gift as a "free gift" (following Jacques Derrida) reveals the power of descriptions in making relations. I argue that the transformation of an unsuccessful gift into a mythical free gift is a product of magnification and supplementation, with concomitant effects on forms of sociality and personhood. I also explore the relationship between gifts and commodities through a focus on what might be termed "inalienable" commodities. [free gift, Derrida, myth, magnification, creative description, gifts and commodities, India]
I n an article entitled "A Free Gift Makes No Friends" (2000) that focuses on the Jain practice of gocari (grazing), wherein renouncers receive food from lay practitioners, James Laidlaw interrogates Jacques Derrida's claim (1994:10-16) that the gift is an impossibility (Laidlaw 2000; see also Argyrou 2007). Derrida suggests three conditions implicit in the idea of a gift. Firstly, there must be no reciprocity. The gift must neither be in return for a previous gift nor anticipate any future return. Gift giving cannot, in short, involve any calculation or interest. Secondly, and for the first condition to be met, the recipient should not recognize the gift as a gift, as this would lead to a feeling of indebtedness and the obligation to make a return. Thirdly, the giver should also not recognize the gift as a gift. Even if the giver does not expect reciprocity from the recipient, the recognition of having given a gift would still allow the giver to derive satisfaction or gratification from his or her action; that is, the recognition would still lead to an exchange, even if only internal to the giver. Logically, then, the thing cannot exist as a gift because as soon as it does (to either giver or recipient), it becomes part of a cycle of exchange, thereby ceasing to be a gift (also see Jenkins 1998; Laidlaw 2000:621). ${ }^{1}$ A gift that seeks to beget nothing whatsoever directly is what Laidlaw calls a "free" or a "pure" gift. The free or pure gift is distinct from what Laidlaw (2000:626) terms the "Maussian" gift, which looks disinterested and voluntary but is, in fact, interested and obligatory and for which giver and recipient expect reciprocity (Mauss 1990).

Laidlaw shows that something approximating the free gift can be seen in the receipt of food by Jain renouncers from lay devotees. As far as the renouncer is concerned, the acceptance of food cannot cause any reciprocal relationship to come about between the two parties; otherwise, the renouncer's path to spiritual fulfilment becomes compromised. The whole encounter is a highly delicate and carefully managed affair. It is hedged about with many prohibitions so as to leave recipients unencumbered and unharmed. No strings are created between the two parties by the giving and receiving of this gift of food. Whatever gratification the giver may feel

AMERICAN ETHNOLOGIST, Vol. 38, No. 1, pp. 47-57, ISSN 0094-0496, online ISSN 1548-1425. (C) 2011 by the American Anthropological Association. All rights reserved. DOI: $10.1111 /$ j.1548-1425.2010.01291.x 
or whatever merit he or she hopes to accrue, the renouncer does not see the food as a gift. Thus, the taking of food (or the filling of the renouncer's bowl) is accomplished in a brusque and businesslike manner. No thanks are offered nor any compliments. However, notwithstanding the very clear guidelines that govern the giving and taking of food, there is often a disjunction between the giver's approach to the encounter and the receiver's. Some donors, for instance, want to create "friends" and actively try to do so-they try to bend the rules, for example, by persuading renouncers to take more of a special dish or by inviting renouncers to make regular gocari visits to their homes. Laidlaw acknowledges that, although the food giving comes close, "this is where [it] differs from Derrida's impossible pure gift" (2000:624).

The question of the systemically crucial unreciprocated gift has exercised other anthropologists. Jonathan Parry (1986) shows that in Hindu India, when such a gift, or dan, is taken, the recipient, who is not allowed by the very terms of dan to reciprocate, courts misfortune, especially if he or she does not pass the gift or its fruits on to others. Dan is explicitly imbued with the spirit of the giver. In accepting dan, the recipient accepts the sins of the gift giver. This is why the gift giver will not take anything back from the recipient. Here, the unreciprocated gift is anything but free. Indeed, as Parry (1986) suggests, the continuing appeal of the ideology of the free gift says quite a lot about societies that hold on to it however impossible it may be to realize in practice. For Laidlaw, the free gift holds a different interest: "The fact that the free gift does not create obligations or personal connections is precisely where its social importance lies" (2000:618). The (almost) free gift allows renouncer-recipients to stay alive while avoiding the social entanglements that chain them to the cycle of births and rebirths. It does not create friends.

The unreciprocated gifts that both Parry and Laidlaw describe from India are oriented toward soteriological ends. Certainly, as Laidlaw (2000:617) points out, Parry has related the pure-gift ideology that governs these unreciprocated gifts to the existence of a developed commercial economy and to an ethicized salvation religion (also see Parry 1986:466-469). My own focus in this article is on one unreciprocated gift in India that, although originating in a commercial and highly differentiated economy, makes no reference to salvation. Furthermore, lying between the impossible and the thinkable (Derrida 1994:10) and being the product of forgetting (Derrida 1994:16), it appears to fulfill Derrida's conditions, but with some interesting twists that, I suggest, following Laidlaw, make the free gift of interest to anthropologists.

Here I ask how a free gift might come into existence, even when it is not the product of strict regulation, as in the Jain case. Can a free gift engender sociality or "make friends"? In answer to both questions I suggest that one might want to look to myth. By myth, I mean here a narration of events that is not empirically true or, at any rate, verifiable as true, but which nevertheless has real social effects. The myth on which I focus does not come out of nowhereit is generated and pinned in place by a few facts, chief of which is an attempt by a man in South India to make a coronation gift to Queen Elizabeth II in 1953. It is this historical attempted gift, Maussian in its intentions and refused by the recipient, that becomes, in mythical accounts of it, a successful gift for which the identified givers do not take credit. Furthermore, for reasons I go into below, the question of reciprocity does not arise. The process of transforming a failed gift attempt into a successfully given gift through rendering in myth is what I suggest brings forth a free gift and makes that gift an enabler of relationships, not between gift giver and recipient but between hitherto unrelated people. One might say, in a Latourian vein, that a matter of fact of narrow interest to a few people (gift giver and recipient), in becoming a matter of wider concern to the Indian public, was transformed, becoming generative.

The particular class of objects to which the gift of this article belongs comprises extremely fine mats hand woven by members of the Labbai subgroup of Muslims of Pattamadai, a small town in Tamilnadu, South India. Pattamadai mats are widely esteemed as beautiful. Their materiality and the enchantment they seem to cast on various people within India is important to the story I tell here. Since the 1950s, Pattamadai mats have been gifted (or attempts have been made to gift them) to important public figures on the international stage, including Queen Elizabeth II, the Dalai Lama, President Mikhail Gorbachev, and Prince Charles and Princess Diana, and to national and regional figures such as former prime minister Rajiv Gandhi, former chief minister of Tamilnadu state Selvi Jayalalithaa, and the president of India, among others.

Nicolai Ssorin-Chaikov (2006) points out that the practice of giving gifts to distant public figures is relatively neglected in anthropology (but see Dutton 2004). This lack of attention ignores the important contribution that a focus on public gifting may make to questions of reciprocity, the relative status of gift givers and recipients, and questions of causality - who is considered the original gift giver who then impels countergifts? Michael Dutton (2004) offers one of the few such analyses, focusing his attention on a basket of mangoes received by Chairman Mao Zedong. Like Dutton, I also consider a single gift, the mat meant as a gift to Queen Elizabeth II. However, unlike Dutton, I focus on the production and effects of a free gift rather than on the receipt of an actual gift. My focus includes the identity and ambiguation of the agency of the gift giver, the presence or absence of a recipient, the mythic dimensions of the gift, and its trajectory in time, space, and the imagination.

Description is an important aspect of this discussion. The particular forms that descriptions take in the 
ethnographic site are generative and creative-they point to what might be termed "indigenous theorizing": the things that people make visible and invisible, how they do so, and why. I explore how tellings and retellings of a particular version of events (verifiable as inaccurate) come to be considered true and to have real social effects. I am interested in the ways in which things and persons (present and absent) are brought into relationships and associated in configurations that become more or less stable through repetitions, creative descriptions, and practices. I am also interested in who or what is made to disappear in these accounts.

\section{A mat to mark a coronation}

In 1952-53, a Tamil Brahmin based in Madras in South India, who was a chief agent of the Royal Insurance Company and whose name was V. A. K. Rangan, hit on a plan to bring himself to the attention of an important public figure: Britain's Queen Elizabeth II, who was to be crowned on June 2, 1953. India had been independent for under a decade, and loyalties, one assumes, are slow to change. India, at any rate, was (and still remains) part of the commonwealth of which Elizabeth II had become head. Mr. Rangan decided to make a coronation gift to the queen. Accordingly, he commissioned a mat from the weavers of Pattamadai. As noted, Pattamadai was, and remains, famous for the very high quality of the mats woven there. Gazetteers and other official publications of the colonial government praised the quality of these mats and commented on their uniqueness (Pate 1917; Rao 1929). A mat had even won a medal at an exhibition of industrial arts and crafts organized by the British government of India (the Delhi Exhibition of 1903; see Watt 1904). Mr. Rangan may well have felt that here was an object that would suit a queen. Taking advantage of the fact that the mats are handmade and that it is possible to weave words into the fabric, Mr. Rangan further decided he would have the weavers incorporate his own name and that of the queen into the one he commissioned. The mat, then, with both names woven into it, would embody the connection with the queen that he so ardently desired.

Mr. Rangan is no longer alive, but older weavers in Pattamadai recall how a relative of his, who was the public prosecutor in the nearest large city, Tirunelveli, liaised between him and the weavers. There was some competition over who would weave the mat when the order first came. In the end, the weaver who quoted the lowest price (Rs 150, or approx. £11) was given the commission. ${ }^{2}$ Whether this competition was because this mat was felt to be special or because commissions for high-quality mats were few and far between is uncertain. ${ }^{3}$ It does seem clear, though, that, as far as the weavers were concerned, the mat, however special, was a commodity-something that would be sold for an agreed price and over which the weaver(s) would have no further rights once the transaction was completed. For the weavers, the mat was not a gift; its buyer was the one who would transform it into a gift.

Mr. Rangan did not meet with success in his attempt to turn the mat into a gift for the queen. Protocol was very strict in the matter of the coronation. Only selected individuals were permitted to make coronation gifts. ${ }^{4}$ All other gifts had to come from collectives. Mr. Rangan tried to salvage the situation by getting the weaver to change the names on the mat. Instead of just bearing Mr. Rangan's and the queen's names, a new gift giver-the Pattamadai mat weavers' association-was added. Mr. Rangan was explicitly identified as the person through whom the present was sent. In this form, the mat went to Delhi. Would or would it not now be acceptable as a coronation gift?

It appeared that it would not. According to the inventory clerk for the London palaces and residences (e-mail to author, August 2005), following a lengthy correspondence between D. J. C. Crawley of the Commonwealth Relations Office and Major Sir Michael Adeane at Buckingham Palace, the mat continued to be classified as a personal gift. ${ }^{5}$ It was therefore deemed unacceptable. The mat then seems to have disappeared. It certainly never reached the queen. This was known in India at the time, albeit only to the small English-reading public. According to a letter dated March 26,1953 , which is part of the above-mentioned correspondence, the refusal of the mat received publicity in the Indian press; reference is made in the letter to an extract from the Madras Mail of February 23, 1953. Time, however, has produced a different and much more successful ending to this story.

In 1964, the mat resurfaced as a successful gift in no less an authoritative text than a government of India census volume devoted to the mat-weaving industry of Pattamadai (Nambiar 1964). P. K. Nambiar writes, "Sri. V.A.K. Rangan, Agent, Royal Insurance Society, Madras placed an order with the mat weavers for a fine mat of value Rs. 150/to be presented to Queen Elizabeth II of England during her coronation on 2nd June 1953. The mat was duly presented to the Queen and was on exhibition along with other presents" (1964:6). How the writer of the 1964 census volume missed or ignored the unsuccessful history of the gifting is difficult to understand, but he did.

Descriptions of the (always acclaimed as successful) gift event underwent further elaborations as time went by. Gradually, Mr. Rangan began to drop out of the picture and other gift givers replaced him. Thus, in 1996, 43 years after the coronation, a newspaper reporter covering a special sale of mats from Pattamadai held in Madras, wrote, "Of course, no lore concerning the mat would be complete without its faery touch-way back in 1948 [sic], out of the wealth of India's handicrafts, it was a finely textured Pattamadai mat which was chosen as India's wedding gift [sic] to the then Princess Elizabeth" (Chari 1996). ${ }^{6}$ In 2004, another reporter wrote, "A Pattamadai mat hangs in the corridors of 


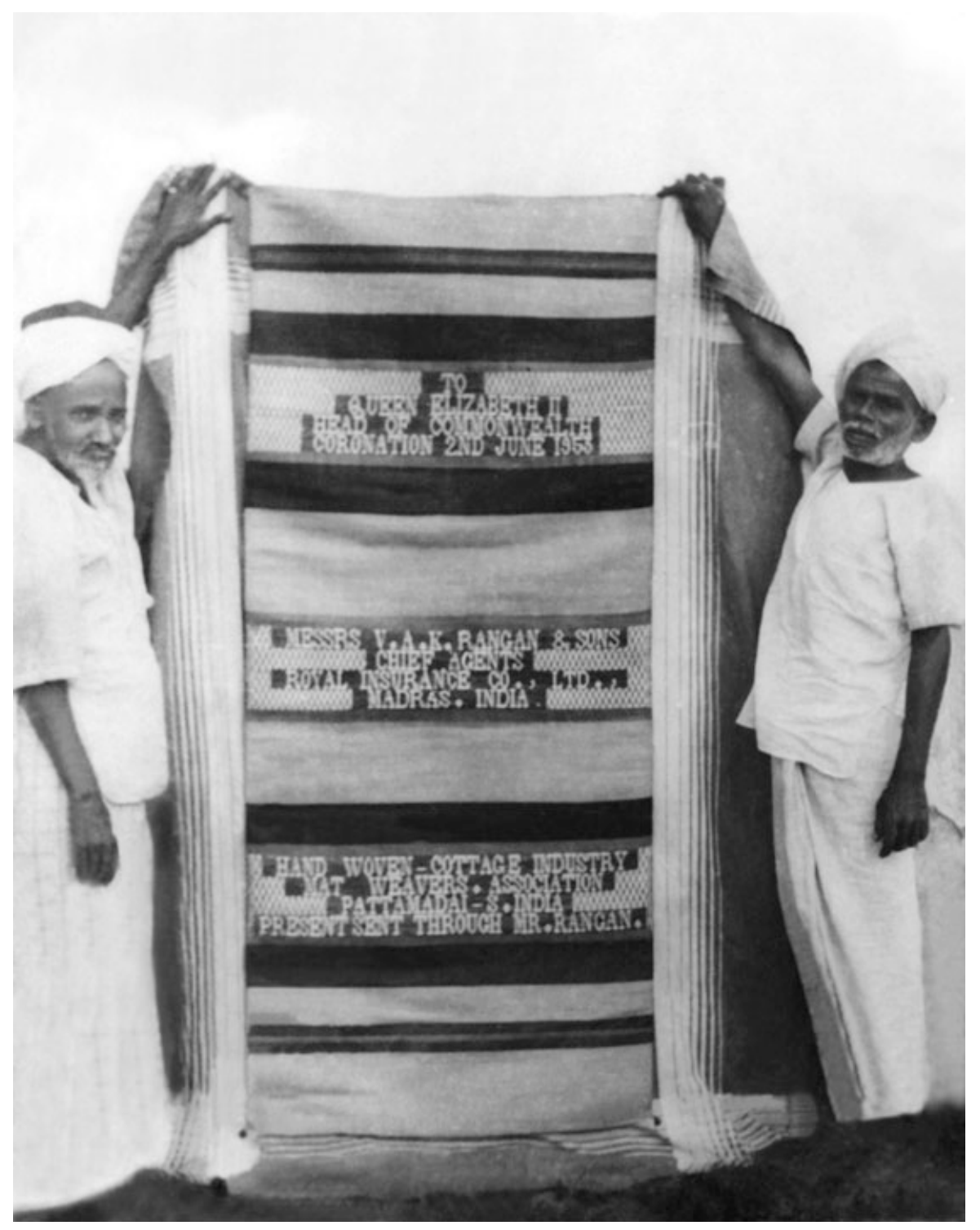

Figure 1. The final form of the mat for the queen. I am grateful to the Pattamadai Labbai Fine Mat Weavers' Co-operative Society for permitting me to reproduce this photograph here.

Buckingham palace. A special gift by the Lebbai Muslim artisans of the village to Queen Elizabeth II on her coronation, it made its way to London in 1953" (Hindu 2004).

Indeed, few of the many newspaper and other articles on Pattamadai (which serve to attract more people to the mats and sometimes to the town) fail to mention the gift for Queen Elizabeth II, even if there seems to be little speculation about the intentions of the givers or consensus on their identity. ${ }^{7}$ No doubt is ever raised that the queen was a happy and pleased recipient of the mat made for her. Time, then, can transform a refused gift into a successful one.

The relationship between time and the gift has exercised Pierre Bourdieu as well as Derrida. For Bourdieu, the passage of time is what enables the harmonious discharge of the obligation incurred in accepting a gift. Too soon a response, and the exchange looks like barter; too late, and one risks losing the connection between the gift and the countergift, making each giving seem as if independent of the other (Bourdieu 1992:105-106). Ssorin-Chaikov puts Bourdieu's point more strongly: "With the subtraction of time, the giftness is ... lost" (2006:362).

Derrida, like Bourdieu, recognizes that gifting is more complicated and less obvious than it seems, but he has a different take on time and the gift. Time, he writes, is what makes the gift impossible. The instant a gift is given and recognized as such, it vanishes. What remains is an exchange 
or the conditions for an exchange. This may be because the giver recognizes the gift as such and takes from this fact a warm glow of satisfaction or pride. In other words, the giver gets something (even if only from him- or herself) from the act of gifting. Or it may be because the recipient recognizes the gift and feels obliged to make a return, thereby transforming the gift into a debt. Even over a long period of time, little separates giving from taking. As long as cause and effect unfold in time, for Derrida, there is no such thing as a (free) gift. ${ }^{8}$ Both Bourdieu and Derrida recognize that gifting involves a certain degree of masking and misrecognition. When these cease to hold sway (either because the passage of time is collapsed, showing straightforward reciprocity, or because time has elapsed, allowing recognition of a gift as such), the gift is revealed not as a gift but as a component of exchange.

One might ask, keeping the question of time very much in mind, when is a gift a gift? Is a gift recognizable at the moment of giving? Or at the moment of acceptance? Or at the moment of reciprocity? When the gift is integral to social life (as the Maussian gift is), it is often unnecessary to separate the two moments of giving and acceptance, as they are usually very proximate. Indeed, the one is so predicated on the other that, "in setting up his schemata of the social phenomenon of the gift, Mauss pays little attention even to the possibility of rejection or refusal" (Young 1985:96). There is gift (giving and accepting), and then countergift (giving and accepting), and so on. For Derrida, of course, the gift should never be recognized or it ceases to be a gift, so the above questions do not arise. But suppose the recognition of a successful gift comes from entirely outside the parties involved in giving, receiving, or, indeed, refusing to accept the gift? What kind of gift would that be?

\section{The appearance of a free gift}

To recapitulate, I began with a commodity that was commissioned as a gift. The identity of the gift giver was perforce hidden to make the gifting possible. The makers, who were producers of an alienable commodity, were deliberately and falsely identified as the gift givers. But the gift never reached its intended recipient. It was deemed unacceptable. Historically, then, there was no gift-not as far as the weavers were concerned (one of them had merely sold something), not as far as the queen was concerned (she never received or, indeed, even heard of the gift), and not as far as Mr. Rangan was concerned (his intended gift was rejected, making it, at most, a failed gift). However, over time, a mythical story was produced of a successful gift that did reach the queen. Apart from one mention of Mr. Rangan in the census volume, the identity of the successful gift giver is in flux. Sometimes the Indian nation is given credit, sometimes the collective entity of the Pattamadai weavers, and sometimes the Indian state. Given time and the right conditions, then, a nongift can become a gift of a very different kind than originally intended.

But what kind of gift is it? I suggest identifying it as a free or pure gift. This free or pure gift is the product of four factors, on which I expand in subsequent discussion: The first is a slippage between historical accounts of an attempt to gift and later, widely circulated and believed mythical accounts of a successful gift, constructed by commentators who were not in any way involved with the gifting; in both historical and mythical accounts in this case, the identity of the recipient (the queen) and of the gift object (a specially made Pattamadai mat) are the only things that remain stable. The second factor involves descriptions that identify the mat and its makers with India's craft heritage. The third, closely connected to the second, is the valorization of the thing given, which sheds luster on givers and recipients. The fourth is the thing's original status as a commodity.

Elsewhere, I have discussed the importance of the category of traditional craft to the idea of the Indian nation (Venkatesan 2009a, 2009b). The traditional craft producer who makes objects that are identified by elites as traditional crafts (note the circularity) is celebrated within India as embodying the essence of the Indian nation. A heterotopia (Foucault 1986; see Venkatesan 2006, 2009a, 2009b), craft is seen as "timeless yet contemporary" and, in this mode, is used by several state and nonstate agencies to anchor modern India to ancient roots. This is simultaneously a political, economic, and aesthetic project (see, e.g., Bundgaard 1999; Durrans 1982; Greenough 1995; Venkatesan 2006, 2009a, 2009b).

For Bourdieu, two kinds of masking allow the gift to exist. The first is the masking and misrecognition allowed by the separation in time between giving and taking (or taking and giving). The second is the systematic emphasis on the symbolic aspects of the activities and relations of production. This prevents the economy from being grasped as an economy, that is, as a system governed by the laws of interested calculation, competition, or exploitation. Nature is idolized and human activity is not recognized as labor (Bourdieu 1977:171-172). This second kind of masking is very visible in the case of traditional Indian craft. The Indian craft producer has, for instance, been described as "a part of the universe, giving expression to ideals of eternal beauty and unchanging laws, even as do the trees and flowers whose natural and less ordered beauty is no less God-given" (Coomaraswamy 1909:75). Craftwork has been described as a calling (Coomaraswamy 1909:75). Indeed, specifically writing about Pattamadai mats, a writer goes so far as to claim that "it is not easy to trace [their] origin ... a real work of aesthetics rather than the vision of the matweaver" (Syed Muthahar 1995).

Craft and nation are often conflated. Brian Durrans cites a government of India brochure: “There is nothing so Indian as Indian handicrafts" (1982:18). For Ananda K. 
Coomaraswamy (1909), as for other commentators, Indian craft was timeless, materializing not an individual's vision but a community's, indeed, the entire nation's. Craft's timelessness makes the nation timeless, and vice versa.

Although all the accounts of the gift for the queen identify a specific giver (Indian nation, Indian government, producer group), this giver is a complex entity because of the relationship posited between nature, nation, and craft. Neither the Indian state nor the craft producer possesses the nation or its craft traditions. They are but stewardscharged with protecting, preserving, and continuing the craft tradition and through it, the nation. One may mobilize Vassos Argyrou's suggestion here that the gift is that of human purity and innocence. This gift "can be said to exist only insofar as there are no giving agencies" (Argyrou 2007:302). If one is a steward, the gift is not one's to give. One cannot alienate it but only pass on its fruits, which are the things themselves. The worthiness of the recipient is only a confirmation of the worth of the gift object. The recipient (as in the case of the queen) does not need even to acknowledge the gift. Reciprocity is not what is at stake here. ${ }^{9}$ And, anyway, as far as the makers are concerned, reciprocity has already occurred, as what they made was a commodity.

Christopher A. Gregory defines gift exchange thus: an "exchange of inalienable objects between people who are in a state of reciprocal dependence that establishes a qualitative relationship between the transactors" (1982:100). Commodity exchange, by contrast, is the "exchange of alienable objects between people who are in a state of reciprocal independence that establishes a qualitative relationship between the objects exchanged" (Gregory 1982:101). ${ }^{10}$ The difference between commodity and gift seems fairly clear. However, what of the commodity that looks, or is made to look, like a gift? I am thinking here of the ways in which the heterotopic nature of craft in India depends on productive confusions wherein the commodity nature of craft objects is suppressed in favor of emphasizing their giftlike attributes. Perhaps some commodities "feel more right" when placed in the gift register. This means that commercial craft producers are fairly consistently cast as gift givers in elite Indian discourses.

Notwithstanding this, from various discussions that I have had with them, weavers do not claim any essential attachment to objects they sell or connections to people who buy them. ${ }^{11}$ As sellers of commodities, which may be turned into gifts, the weavers remain disinterested (though enthusiastic) makers. Thus, no matter how much credit they are given in accounts of the successful gift to the queen (or other such gifts), they do not take responsibility for the gift, although they do for the mat. The thing is sold and that is that. However, and this is a peculiarity of the construction of craft in India, in other people's minds certain handmade objects are never wholly alienated from the makers, even if they are sold as commodities. Here, makers remain a part of things. This might appear imaginatively or ideologically to turn seller-makers into gift givers, but makers know that they are not gift givers (nor would they be willing to be, because their livelihood is based on being paid for making the objects given as gifts).

Let me run the above case through Derrida's three conditions: There must be no recognition of the gift by the giver (who otherwise will, at the very least, feel a glow of satisfaction) or by the recipient (who will otherwise feel indebted), and there must be no reciprocity.

If one takes Mr. Rangan as the gift giver, the mat he commissioned to give to the queen was far from a free gift. As far as is known, Mr. Rangan's gift was meant to make a connection, at best, or to increase the fame of the gifter. He could be spoken of, and speak of himself, as a man who had made a gift to the queen. This, at least, would give him satisfaction. It would bring him something. But Mr. Rangan was never allowed to actually give his gift, even though he tried quite hard to get around its refusal. The historical attempt to gift was a failure. But the successful mythical gift endures.

As far as the mythical gift is concerned, the question of the gift giver becomes muddled. Mr. Rangan drops out of the picture, and other entities replace him. But they do not take credit for the gifting, even if they believe the gift was successfully given. From what older weavers say, to them, the mat remained a commodity (albeit a special one). They gave up rights over it when they sold it. Likewise, the Indian state also does not claim credit for the gifting. By the time the gift comes to be attributed to the Indian nation, there is no real giving agency anymore, only stewards of a timeless tradition who pass on the fruits of this tradition.

To turn to the second condition: Authoritative sources confirm that no gift ever reached the recipient; indeed, it was refused, and she therefore did not have to acknowledge a gift or feel any debt. With regard to the historical gift, there was, then, nothing to reciprocate as far as the intended recipient was concerned. Turning to the successful mythical gift, the responses I received from the Royal Household clearly indicate that later accounts of the mat never reached the queen's staff. There is, then, no recognition of a gift by the recipient. Furthermore, in none of the mythical romanticized accounts is the question of reciprocity raised, even implicitly. Instead, the sense they convey is of a gift worthy of a queen and of a queen worthy of this gift. The third condition too is met.

The successful mythical gift cobbled together from the unsuccessful historical gift and larger ideas about craft is undoubtedly the product of maskings, conflations, and cumulative misrecognitions over time. Even within accounts that identify a successful gift, a gift giver, and a recipient, because of the slippage between myth and history, the mat for the queen begins to look like a free or pure gift. Furthermore, it is one that acts in the world. 


\section{Presence and absent-presence in friend making}

I suggested above that the materiality of the mat and the enchantment it appears to cast on various people who encounter it is an important consideration in understanding, first, why Mr. Rangan chose it as a suitable coronation gift and, later, why the mythical account arose. Below, I attempt to follow the mat from loom to myth.

Once the mat left Pattamadai for Madras, where Mr. Rangan was based, the weavers never saw it again. The details of its journey are unclear, and one can only piece together fragments from different accounts. All that is known for certain is that the gift was refused by Buckingham Palace but that the writer of the 1964 census volume believed it to have been successfully gifted. The same writer claims that the mat, which he describes as a "superb specimen," went on display with other coronation gifts and that "it was at this stage that the All India Handicrafts Board [the newly formed apex body for the promotion of traditional crafts in independent India] became alive to the existence of this craft. After this things began to move swiftly" (Nambiar 1964:6). Kamaladevi Chattopadhyay, the founder chairperson of the All India Handicrafts Board, traveled to Pattamadai in 195354 along with a team from the Handicrafts Board. Older weavers in Pattamadai recall Chattopadhyay's visit and confirm that the mat for the queen was what brought her to them. Chattopadhyay encouraged the Labbais to form a handicrafts cooperative society. The newly formed cooperative, formally registered in 1954, was given financial assistance by the All India Handicrafts Board as well as by other national and regional government agencies. Labbais who needed new looms were given them. Some years later, weavers who did not own their houses were given land as well as assistance to build homes. The Pattamadai Labbai Fine Mat Weavers' Co-operative Society still exists today and receives support from the state and national governments.

It seems reasonably certain that it was the mat that sparked Chattopadhyay's, and the government of India's as well as the state and local governments', interest in Pattamadai. Years later, Chattopadhyay was to write that "the ivory-white mat, simple, with no trace or design is a superb piece, for its very simplicity has an allure, with its melting soft surface" (1995:108). Chattopadhyay's efforts, through the All India Handicrafts Board, and later, the Crafts Council of India (a pan-Indian NGO that she founded), subsequently transformed and solidified the Labbais of Pattamadai into a "traditional craft community." ${ }^{12}$ The effects of the mat for the queen, direct and indirect, can, then, be traced and adduced, but what of the mat itself? As far as I can tell, after 1953, it was never seen again but was only heard of. But, although physically absent, the "queen's mat" is imaginatively present in the writing and serious speech acts of almost everyone concerned with the mat-weaving industry. Indeed, it is the absence of the physical mat that, to some extent, generates the narrative possibilities for and new capacities of the successfully gifted mythologized mat to produce social effects. ${ }^{13}$

The Labbais of Pattamadai continue to receive attention from governmental and nongovernmental organizations concerned with promoting and developing traditional Indian crafts. Designers come to the town and work with weavers and traders, creating new motifs and combinations. New urban markets have opened up for the mats. All of this means that members of the group frequently come into contact with physically and socially distant urban upper-class, caste, and powerful sections of Indian society interested in traditional Indian craft. Weavers and traders are interviewed by journalists, especially during sales of Pattamadai mats in various Indian cities.

Let me underscore the importance of this attention. The Labbai Muslims of Pattamadai are poor, with few financial safety nets, little access to higher education and the formal sectors of the economy, and no ties to agriculture. They are mainly involved in the informal sectors of the economy. Like millions of rural landless poor, the men migrate within and beyond India to find work; many are petty entrepreneurs who sell seasonal goods in tourist towns. Women rarely leave the town, working instead in their homes, either weaving mats or rolling leaf cigarettes (beedis). Under normal circumstances, they would merely be statistics to the sections of society that today celebrate them as "traditional craft producers." Now, in however limited and constrained a way, some of them meet presidents and prime ministers. Politicians and bureaucrats dispense largesse to the mat-weaving industry. Although it would be too much to say that these are all the direct effects of the mat for the queen, there is certainly a ripple effect: like the everexpanding ripples across water when a stone is dropped into it, the effect of the queen's gift can be followed outward incrementally.

The mat that was meant to be an intermediary between Mr. Rangan and Queen Elizabeth II thus became, instead, in Bruno Latour's words, a mediator, transforming, distorting, and modifying the meanings it was supposed to carry, leading in multiple directions. Its inputs did not determine its outputs (Latour 2005:39). But, unlike Latour's mediator, which is usually materially present, a physically absent object does some of the crucial acting in this story. This is because of the mediating and partial accounts of various actors, which have turned the mat for the queen into a free gift. The physical mat began the process of making friends for the Labbai weavers of Pattamadai. The absent, indeed, invisibly present mat that was mythologized into a successful free gift has continued this process by being invoked time and again in various fora. I am tempted to say that the accounts that build on the mythical successful gift are themselves also free gifts: this time, from journalists to 
the mat-weaving industry. And, like the gift to the queen, the accounts also produce social effects that promote the mat-weaving industry. They continue to make friends for the weavers of Pattamadai: contacts, customers, and wellwishers in elite developmental, governmental, and other circles throughout India and even beyond.

No one anticipated the effect the mat for the queen would have, and, indeed, its agentive and mediatory qualities only become apparent in light of the enormous changes to the lives of the Labbais of Pattamadai caused by their identification as craft producers and therefore as objects and beneficiaries of development. This, it must be remembered, began with Chattopadhyay's visit to Pattamadai after she saw the coronation mat in 1953. Large numbers of Pattamadai mats have since been gifted to several important personages by Labbai weavers, other individuals, and representatives of the national and regional governments. ${ }^{14}$ The prototype they draw on is the mat for the queen. Few of these mats have come close to achieving what the queen's mat did, but they continue to draw attention to the matweaving industry and, indeed, recursively, to the mythical free gift.

\section{Conclusion}

Anthropology's enduring interest in gifts stems from the way in which gift exchange is seen to create and maintain social relations between persons or groups. Further, gifts, as Marilyn Strathern shows, are revelatory. In Melanesia, the flow of reciprocal gifts from one person to another is a measure of capacity. A man's capacity to give is measured by means of his gifts to his exchange partners; his capacity to elicit an equivalent measure (immediately or at another time) shows his judgment in choosing exchange partners. Both giving and eliciting confer prestige because they point to capacity and sagacity. A man is the measure of his exchange partner. Here, gifts render men (or corporate persons) not just commensurable but, in Strathern's (1999:214) words, alternative versions of each other.

Gift giving between unequal partners is also revealing, this time of hierarchy. Tributary gifts both reveal and maintain hierarchical relations. The recipient may simply return a token, the same thing given and accepted; he or she may not even have to return anything because there is no debt to pay off. In an article that focuses on gift giving to Josef Stalin, Ssorin-Chaikov (2006) argues that a feature of gifts to state leaders and other public figures is that the gift givers do not expect direct reciprocity from these public figures. This is because the gifts given to the leader are seen as countergifts (or thank-you gifts) for the leader's original gift of stability, governance, benevolence, and so on. No countergift can ever match or measure up to the gift(s) given by the leader. The two are simply not commensurate. But this is not to say that such gifts cannot be measured or used as measures.
Tributary gifts can be competitive (e.g., between different gift givers), they may be displayed by the recipient as a mark of prestige, and gifts from all over the world can be used as a measure of the recipient's reach.

Commodities are amenable to measurement in terms of money. A gift can more or less successfully fold over a commodity, transforming it by eclipsing its monetary value through the addition of other values (descriptively, physically, or both-e.g., by removing a price tag or adding wrapping paper). The gift object here moves between different spheres of value (first of commodity and then of gift), ${ }^{15}$ but it is still capable of being measured-by its price, uniqueness, or desirability and, in the case of a reciprocal gift, what it elicits from the recipient in the form of countergifts. Commodity concepts and gift concepts, then, are not radically opposed (indeed, producers of commodities and wholesale buyers often invoke idioms of kinship or gifts in their negotiations with one another).

To a certain extent, Mr. Rangan's historical (although unsuccessful) gift to the queen may be understood as a tribute-it is unclear whether he ever expected any reciprocity. Just having her accept his gift would have pointed to his capacity (to purchase a suitably expensive and unique commodity and then give it as a gift) and thereby enhanced his prestige. Of course, his gifting attempt failed even though it was rendered successful in myth. In the process, his gift became, in my analysis, a free gift with no recipient, no gift giver, and no expectation of reciprocity.

What makes a free gift an ethnographic object? For Derrida, the free gift is an aporia, an impossibility, but it is one that people nevertheless strive to make possible. It is certainly encountered in everyday discussions of charity, altruism, and so on, and also ethnographically. To think through why the ideal of the free gift endures, I draw inspiration in this final section from Alberto Corsin Jimenez's (2004, 2005) work on proportionality and magnitude. He writes, "Our anthropological task could be redefined thus: How do our visions of humanity become gigantic? Or inversely: how does the gigantic resize what it means to be a person?" (Corsin Jimenez 2004:17). The free gift, I suggest, magnifies people's sense of themselves, their relations with one another and to "gigantic" entities that confront human life yet exceed it (see Corsin Jimenez 2004:16, whose comments on this point follow Weiner 2001:163-164).

Before I expand on this point in relation to my own example of a free gift, let me return briefly to Laidlaw's ethnography. The problem that Laidlaw successfully unravels is the trouble that is taken in a radically soteriological religion not to create social relations. "Jain society" (comprising the two abstract orders of laity and renouncers), he writes, rests on a system of exchange made up, in real lived time, of unreciprocated gifts from lay Jains to renouncers (Laidlaw 2000:626); gifts given might bring their own reward at some other time or in another life but there is no, and, indeed, 
cannot be any, reciprocity or expectation of reciprocity from recipients of particular gifts. Otherwise, renouncers could not be renouncers. As far as givers are concerned, the free gift enables lay devotees to attempt to meet the ethicized demands of their souls, which seek freedom from time and the world but are bound by the actions of the persons in whose bodies they reside and who are still committed to worldly success and efforts. This is why, ideally, the giver should take no satisfaction from the gift, as this compromises the meritorious act of giving to a worthy recipient. The soul is gigantic, and confronting it and being true to it resizes the person, shapes his or her ideas of what it is to lead a good life. Indeed, the good life is impossible unless one becomes a renouncer, and, even then, the path to salvation may be compromised by the very fact of living.

But, what of the mat for the queen, a gift that has simply vanished as a tangible object but is present as a mythical historicized object that, moreover, takes on the appearance of a free gift? How can it be measured? And what does it measure? To what kinds of gigantic entities does my mythologized free gift point? I would suggest that the gigantic entities that the queen's mat enables persons to confront (thereby magnifying their biographical life-projects) are the nation, craft, and time itself. This is because of the ways in which indigenous elite theorizing and description locates mats as craft objects within the above entitiesand the relationship of essence that binds craft to nation and both nation and craft to a time without measure that flows from an ancient past to a limitless future. Supporting makers (by buying the mats, using them, gifting them), within this worldview, simultaneously means resizing oneself in relation to these gigantic entities and making oneself meaningful.

This is why the mythical free gift about which I write here actively engenders social relations. Every evocation of it makes, for its makers, friends. Of course, this makes it amenable (even if there is no reciprocity) to being analyzed like other anthropological gifts that create and maintain relationships between different kinds of people; indeed, the mythicized free gift can be seen as a node in a network comprising diverse kinds of people, things, utterances, and institutions.

In the main, this article has been about descriptions and what they do. At the heart of it is a transformation of an unsuccessful gift into a mythologized successful free gift. Through the shifting of scales and magnification in description, weaver becomes craft producer; gift giver becomes weaver community, nation-state, or nation; the gift becomes an example of India's craft tradition. What could be described within the terms of an algebraic relationship (Corsin Jimenez 2004) - that is, the historical mat is an unsuccessful gift because it cannot be slotted into the relational matrix of a successful gift with a giver and a recipient; the mythical mat is a successful gift because the descriptions clearly identify a giver and a recipient-here becomes, by the process of description, a mythologized free gift precisely because of the magnification of the gift and of the entities identified as gift givers and the consequent obliteration of the expectation of reciprocity.

Strathern's (1999:238) notion of "supplementation," with its double meaning of surplus and displacement, is useful here. A portion of the knowledge about the historical mat (that it was commissioned as a gift for the queen) is supplemented by descriptions of craft and its essential relationship to the nation. This augmentation displaces both the commodity nature of Pattamadai mats and the information about the lack of success of the gift. The supplementation is the result of indigenous elite theorizing about craft and about the nation-its essence and timelessness embodied in craft objects and producers. But the importance of exchange remains. The mythical free gift enhances the circulation as commodities of other Pattamadai mats within and beyond India. It adds value to the mats as commodities by virtue of the relationships that it was deemed to have created, variously, between the weavers and the Indian state and nation and Queen Elizabeth II. People seem to want to buy Pattamadai mats to give as gifts or for themselves partly because they are enchanted by a gift worthy of a queen and, conversely, a queen worthy of this gift. I finally return to the makers who, even though they believe that the queen did receive the mat, know that they did not give her the gift; they are, nevertheless, not averse to evoking the gift in serious speech acts pertaining to craft. This evocation enables the weavers to resize (magnify) themselves and the mats they continue to make to earn their livelihoods. They can take pride in the "fact" that they produce objects that a queen would be glad to receive, and, at the same time, they know that this will help them sell more mats.

\section{Notes}

Acknowledgments. The main inspiration for this piece is indubitably James Laidlaw's thought-provoking article "A Free Gift Makes No Friends" (2000). Simon Schaffer's and Eduardo Viveiros De Castro's comments and feedback on a paper I gave at James Leach's Description and Creativity conference (Cambridge, 2005) have guided my thinking on the question of descriptions and their effects. James Laidlaw and Alberto Corsin-Jimenez have generously commented extensively on this article. Matei Candea, James Delbourgo, Karen Sykes, Chris Gregory, and Jonathan Woolf have been kind enough to read early versions. Students in my Objects of Analysis course asked questions and commented on this material. Finally, I would like to thank the editor of American Ethnologist and the two anonymous reviewers for their penetrating and thoughtprovoking comments. I would also like to thank Linda Forman for her sensitive and astute copyediting. Any problems that remain are, of course, my responsibility.

1. Laidlaw lists four conditions, but I see three and a conclusion. 
2. Between 1950 and 1959 , £1 was valued at Rs 13.3.

3. N. Rao (1929) certainly gives the latter impression-he writes that the high-quality mats of Pattamadai were so fine and slippery that they did not have any obvious use.

4. I do not go into the reason for this refusal to accept gifts from unknown individuals, but it is tempting to speculate that the question of reciprocity might lie at the heart of it.

5. I have been informed that access to this correspondence, held by the Royal Household, is restricted for the duration of the current reign.

6. Princess Elizabeth was married in 1947. There is no record of a mat having been given to her as a marriage gift. Weavers too only speak of making the coronation gift. To explore why the mat may have been transformed into a wedding gift in this account, see Venkatesan 2009a:ch. 7.

7. The following is a very small selection of articles that mention the mythologized gift to the queen: Basu 2005, Bhaskar 2008, Kumar 2005, Kurien 2008, and Sundaram 2002.

8. It seems to me that Derrida's argument that the gift is impossible is based on a zero-sum type of logic, wherein giving and taking are equally balanced out. It might be fruitful to explore perceptions of giving and taking that include emotions such as regret as well as retrospective calculations and unanticipated bonuses.

9. This kind of gifting, of course, is very different from the Maussian gift, which is given by an individual or clearly defined group that, collectively or in the form of the chief, calculates and expects a return.

10. I do not go into an extended critique of this pair of definitions here, but see Appadurai 1986 and Laidlaw 2000. Also see Gregory 1997, especially chapter 2 .

11. Unless, that is, the buyers are regular wholesalers.

12. To explore the ramifications of belonging to a traditional craft community, see Venkatesan 2006.

13. I thank James Delbourgo for encouraging me to make this point strongly.

14. For a discussion of two such gifts, see Venkatesan 2009a:ch. 7.

15. Although Appadurai (1986) points out that the movement of an object from one state to another may give rise to contestations that, in turn, may reveal cultural assumptions about suitability for exchange, value, social change, and so forth.

\section{References cited}

Appadurai, Arjun, ed.

1986 The Social Life of Things: Commodities in Cultural Perspective. Cambridge: Cambridge University Press.

Argyrou, Vassos

2007 The Philosopher's Gift. Critique of Anthropology 27:301318.

Basu, Soma

2005 The Carpet Makers. Hindu (Madras), August 14. http:// www.thehindu.com/thehindu/mag/2005/08/14/stories/20050 81400210400.htm, accessed September 30, 2010.

Bhaskar, P. G.

2008 The "P" in My Name. Khaleej Times Online (Dubai), September 12. http://www.khaleejtimes.com/index00.asp, accessed September 30, 2010.

Bourdieu, Pierre

1977 Outline of a Theory of Practice. Richard Nice, trans. Cambridge: Cambridge University Press.

1992 The Logic of Practice. Richard Nice, trans. Cambridge: Polity Press.
Bundgaard, Helle

1999 Indian Art Worlds in Contention: Local, Regional and National Discourses on Orissan Patta Paintings. Richmond, UK: Curzon.

Chari, Pushpa

1996 The Wonder of the Pattamadai Mat. Hindu (Madras), February 25.

Chattopadhyay, Kamaladevi

1995[1975] Handicrafts of India. New Delhi: Indian Council of Cultural Relations.

Coomaraswamy, Ananda K.

1909 The Indian Craftsman. London: Probsthain.

Corsin Jimenez, Alberto

2004 The Form of the Relation, or Anthropology's Enchantment with the Algebraic Imagination. Unpublished MS, Department of Social Anthropology, University of Manchester.

2005 Changing Scales and the Scales of Change: Ethnography and Political Economy in Antofagasta, Chile. Critique of Anthropology 25(2):155-174.

Derrida, Jacques

1994 Given Time, vol. 1: Counterfeit Money. Peggy Kamuf, trans. Chicago: University of Chicago Press.

Durrans, Brian

1982 Handicrafts, Ideology and the Festival of India. South Asia Research 2(1):13-22.

Dutton, Michael

2004 Mango Mao: Infections of the Sacred. Public Culture 16(2):161-187.

Foucault, Michel

1986 Of Other Spaces. Jay Miskowiec, trans. Diacritics 16(1):2227.

Greenough, Paul R.

1995 Nation, Economy, and Tradition Displayed: The Indian Crafts Museum, New Delhi. In Consuming Modernity: Public Culture in a South Asian World. Carol A. Breckenridge, ed. Pp. 216-248. Minneapolis: University of Minnesota Press.

Gregory, Christopher A.

1982 Gifts and Commodities. London: Academic Press.

1997 Savage Money: The Anthropology and Politics of Commodity Exchange. London: Routledge.

Hindu

2004 Item about mat hanging in Buckingham Palace. Hindu (Bangalore), March 3.

Jenkins, Tim

1998 Derrida's Reading of Mauss. In Marcel Mauss: A Centenary Tribute. Wendy James and N. J. Allen, eds. Pp. 83-96. Oxford: Berghahn.

Kumar, Vinaya

2005 Royal Mats Fit for Maharajas. Deccan Herald (Mysore), September 4.

Kurien, Mini Chandran

2008 Mats of Faith. Mumbai Mirror (Mumbai), October 18. http://www.mumbaimirror.com/index.aspx?Page=article \&sectname=Lifestyle\%20-\%20Sunday\%20Read\&sectid=82 \&contentid $=2008101920081019023457113 f 7 b a 09 \mathrm{e} 3$, accessed September 30, 2010.

Laidlaw, James

2000 A Free Gift Makes No Friends. Journal of the Royal Anthropological Institute 6(4):617-634.

Latour, Bruno

2005 Reassembling the Social: An Introduction to ActorNetwork-Theory. Oxford: Oxford University Press.

Mauss, Marcel

1990[1924] The Gift: The Form and Reason for Exchange in Archaic Societies. W. D. Hall, trans. London: Routledge. 
Nambiar, P. K.

1964 Fine Mats of Pattamadai. In Census of India 1961, vol. 9: Madras, Part VII-A-IV, Handicrafts and Artisans of Madras State. Madras: Government Press.

Parry, Jonathan

1986 The Gift, the Indian Gift and the "Indian" Gift. Man (n.s.) 21(3):453-473.

Pate, H. R.

1917 Madras District Gazetteers, vol. 1: Gazetteer of the Tinnelvelly District. Madras: Government Press.

Rao, N.

1929 Report on Survey of Cottage Industries. Madras: Government Press.

Ssorin-Chaikov, Nikolai

2006 On Heterochrony: Birthday Gifts to Stalin, 1949. Journal of the Royal Anthropological Institute (n.s.) 12(2):355-375.

Strathern, Marilyn

1999 Property, Substance and Effect: Anthropological Essays on Persons and Things. London: Athlone.

Sundaram, Lakshmi

2002 Rural Interlude. Hindu (Madras), February 24. http:// www.hinduonnet.com/mag/2002/02/24/stories/20020224005 60700.htm, accessed September 30, 2010.

Syed Muthahar

1995 University Bid to Revive Dying Skill. Hindu (Madras), November 23.

Venkatesan, Soumhya

2006 Shifting Balances in a "Craft Community": The Mat Weavers of Pattamadai, South India. Contributions to Indian Sociology (n.s.) 40(1):63-89. 2009a Craft Matters: Artisans, "Development" and the Indian Nation. Hyderabad: Orient Blackswan.

2009b Rethinking Agency: Persons and Things in the Heterotopia of "Traditional Indian Craft." Journal of the Royal Anthropological Institute 15(1):78-95.

Watt, George

1904 Indian Art at Delhi 1903, Being the Official Catalogue of the Delhi Exhibition, 1902-1903. London: John Murray.

Weiner James, $\mathrm{F}$.

2001 Tree Leaf Talk: A Heideggerian Anthropology. Oxford: Berg. Young, Michael W.

1985 On Refusing Gifts: Aspects of Ceremonial Exchange in Kalauna. In Metaphors of Interpretation: Essays in Honour of W. E. H. Stanner. Diane Barwick, Jeremy Becket, and Marie Reay, eds. Pp. 95-112. Canberra: Australian National University Press.

accepted July 1, 2010

final version submitted July 23, 2010

Soumhya Venkatesan

Lecturer in Social Anthropology

Social Anthropology

2nd Floor Arthur Lewis Building

University of Manchester

Manchester M13 9PL

United Kingdom

soumhya.venkatesan@manchester.ac.uk 